Computable General Equilibrium Approaches in Urban and Regional Policy Studies 
This page intentionally left blank 


\title{
Computable General Equilibrium Approaches in Urban and Regional Policy Studies
}

\author{
editor Masayuki Doi \\ University of Tsukuba, Japan
}




\section{Published by}

World Scientific Publishing Co. Pte. Ltd.

5 Toh Tuck Link, Singapore 596224

USA office: 27 Warren Street, Suite 401-402, Hackensack, NJ 07601

UK office: 57 Shelton Street, Covent Garden, London WC2H 9HE

\section{Library of Congress Cataloging-in-Publication Data}

Computable general equilibrium approaches in urban and regional policy studies / edited by Masayuki Doi.

p. cm.

Includes bibliographical references and index.

ISBN 981-256-471-3

1. Urban economics--Mathematical models. 2. Urban policy--Mathematical models.

3. Regional economics--Mathematical models. 4. Regional planning--Mathematical models.

5. Equilibrium (Economics). I. Doi, Masayuki.

HT321.C627 2006

307.7601'5118--dc22

2006044631

\section{British Library Cataloguing-in-Publication Data}

A catalogue record for this book is available from the British Library.

Copyright $(9) 2006$ by World Scientific Publishing Co. Pte. Ltd.

All rights reserved. This book, or parts thereof, may not be reproduced in any form or by any means, electronic or mechanical, including photocopying, recording or any information storage and retrieval system now known or to be invented, without written permission from the Publisher.

For photocopying of material in this volume, please pay a copying fee through the Copyright Clearance Center, Inc., 222 Rosewood Drive, Danvers, MA 01923, USA. In this case permission to photocopy is not required from the publisher.

Typeset by Stallion Press

Email: enquiries@stallionpress.com

Printed in Singapore. 


\section{Preface}

The computable general equilibrium or, in short, CGE modeling approach has by now a fairly long history of development and policy analysis applications. Although the main application fields were limited to trade and tax policies earlier, the advances in methodology and computation techniques, improved data availability, and increasing needs for many other aspects of policy studies invited a wider range of CGE modeling applications. The emerging application fields include industrial policies, environmental and health policies, transportation and other infrastructure policies for both developed and developing countries. Study areas for CGE analysis by now are not necessarily on a country basis, but also can be multi-countries, regions, multi-regions, or even small regions or cities.

The underlying factor is that complex economies at different levels are requiring policy innovations of structural impacts rather than fragmental or partial problem solving. This is true on the regional level as well as the national level.

In view of such tendencies, we planned to devote a special issue of Review of Urban and Regional Development Studies (RURDS), for which the editor of this book acts as Managing Editor, for empirical studies in CGE approaches. It was in early 2002 that we released the call for papers for the special issue, and received an unexpectedly large number of submissions. We then used several issues of RURDS as full or partial collections of them until very recently, even after a considerable number of submissions were unfortunately screened out at the refereeing stage.

This made us perceive the strong need for publishing an extensive but handy collection of urban and regional policy studies in CGE approaches. Most authors of the CGE papers in RURDS were willing to join in the book publication project. We also invited some additional authors for general introductions of CGE modeling as well as for empirical studies published earlier and in other journals. As a result, the chapters cover many different aspects of policies and study areas from all over the world, presumably with rich implications for CGE analysts, policy makers, consultants, students, and many others. 
We are grateful for the encouragements and advices consistently given by Dr. Shinichi Ichimura, Professor Emeritus of Kyoto University. We thank all participating coauthors of the book as well as those CGE and related specialists from all over the world who once refereed the papers. The cooperation from both Blackwell Publishing, the publisher of RURDS, and the World Scientific Publishing Co. Pte. Ltd., the publisher of the book, should be acknowledged. This book would never have come into existence without the help from Ms. Juliet Lee, Senior Editor, and Ms. Chean Chian Cheong, Editor, both of the World Scientific Publishing.

MASAYUKI DOI, Professor Institute of Policy and Planning Sciences University of Tsukuba Tsukuba, Ibaraki, Japan 


\section{Contents}

Preface $\quad$ v

\section{Part I: CGE Model Approach}

Chapter 1. Introduction to Computable General Equilibrium Approaches in Urban and Regional Policy Studies

By Masayuki Doi (University of Tsukuba, Japan)

Chapter 2. CGE Model and Its Micro and Macro Closures

By Mitsuo Ezaki (Nagoya University, Japan)

\section{Part II: Tax Policies}

Chapter 3. The Macroeconomic Impact of the IMF Recommended VAT Policy for the Fiji Economy: Evidence from a CGE Model

By Paresh Kumar Narayan (Griffith University, Australia)

Chapter 4. An Applied General Equilibrium Model to Assess the Impact of National Tax Changes on a Regional Economy

By Manuel Alejandro Cardenete (Universidad Pablo de Olavide de Sevilla, Spain) and Ferran Sancho (Universidad Autónoma de Barcelona, Spain)

\section{Part III: CGE Models for Small Cities and Multi-Regions}

Chapter 5. Building Small City and Town: SAMs and CGE

Models Revisited

By Walter Schwarm (West Virginia University, U.S.A.) and

Havery Cutler (Colorado State University, U.S.A.) 
Chapter 6. A Large-Scale Dynamic Multi-Regional CGE Model with an Illustrative Application

By James A. Giesecke and John R. Madden (Monash University, Australia)

\section{Part IV: Infrastructure and Environmental Policies}

Chapter 7. A Computable General Equilibrium Analysis of Efficiency Improvements at Japanese Ports

By Masayuki Doi (University of Tsukuba, Japan), Hidekazu Itoh

(Kwansei Gakuin University, Japan) and Piyush Tiwari

(University of Aberdeen Business School, U.K.)

Chapter 8. Incorporating Local Health in Assessing

GHG Mitigation: An Application to Thailand

By Jennifer C. Li (University of North Carolina at Chapel Hill, U.S.A.)

Chapter 9. Economic Analysis of Urban Land Use and Housing Supply: An Application of Urban Land Use and a CGE Model for Seoul

By Euijune Kim (Seoul National University, Korea) and Jaeuk Ju (Cornell University, U.S.A.)

\section{Part V: Industrial Policies}

Chapter 10. The Economic Importance of the Sugar Industry for Fiji

By Paresh Kumar Narayan (Griffith University, Australia) and Biman Chand Prasad (University of the South Pacific, Fiji)

Chapter 11. A CGE Approach to Measuring the Sectoral Contribution to an Economy: An Application to Western Australian Agriculture

By Helal Ahammad (Australian Bureau of Agriculture and Resource Economics, Australia) 


\section{Part VI: Trade and International Policies}

Chapter 12. The Impacts of Redesigning European Agricultural Support

By Søren E. Frandsen, Birgitte Gersfelt and Hans G. Jensen

(Institute of Food and Resource Economics, Denmark)

Chapter 13. Regional and National Perspectives of China's Integration into the WTO: A CGE Inquiry with Emphasis on the Agricultural Sector

By Xinshen Diao (International Food Policy Research Institute, U.S.A.), Agapi Somwaru and Francis Tuan (U.S. Agricultural Department, U.S.A.)

Chapter 14. Welfare Effects of Trade and Factor Market Reforms in China

By Masayuki Doi (University of Tsukuba, Japan),

Piyush Tiwari (University of Aberdeen Business School, U.K.) and Tetsu Kawakami (Mie University, Japan)

Chapter 15. Sustainable Development and Globalization in a World with Unequal Starting Points

By Brantley Liddle (Max Plank Institute for Demographic Research, Germany)

Chapter 16. The Impact of Japanese Economic Cooperation on Asian Economic Development

By Kenichi Kawasaki (Research Institute of Economy, Trade and Industry, Japan)

Chapter 17. Regional Economic Integration and Its Impacts on Growth, Poverty and Income Distribution: The Case of Vietnam

By Tien Dung Nguyen (National Advanced Training Institute,

Vietnam) and Mitsuo Ezaki (Nagoya University, Japan)

Index 